\title{
A Conceptual Framework of Gastronomy Tourism Development Focusing on Cultural Heritage Valuesin Maha Sarakham Province
}

\author{
Dr.Thirachaya Chaigasem* \\ Assistant Professor, Head of Ph.D Program in Tourism MICE and Hospitality Innovation Management, Faculty of Business \\ Administration and Accountancy, Khon Kaen University, Thailand
}

\section{Mallika Jecan}

Ph.D. Student of Tourism and Hospitality Innovation Management Department, Faculty of Business Administration and Accountancy. Khon Kaen University, Thailand

\begin{abstract}
The Thai local communities are encouraged to conduct their own creative economy, which should cause the added value to the local goods. Knowledge and innovation should be used in the marketing of local products. Because of its richness in cultural and environmental resources, Mahasarakham is one of the fifteen provinces of Thailand and the only province from the Northeast that is appointed as the creative economic city. The present study sought to address the following objectives: The objective of this research was to study and formulate a conceptual research framework for the development of Gastronomy Tourism inMahasarakham Provinceand todevelop a conceptual framework to demonstrate therelationships between the factors of Cultural Heritage Values, Tourists'Motivations,andthe Tourists' Experiences. In this study, a mixed-method approach was applied; specifically; qualitative and quantitative research was carried out. In obtaining quantitative data, a questionnaire was employed as a research instrument. The quantiative data were analyzed through factor analysis, exploratory factor analysis, confirmatory factory analysis and structural modelling analysis. As for collection of qualitative data, in-depth interviews and focus group discussions were conudcted. The participants in in-depth interviews in three districts consisted of seven persons working in the government sector, nine of those in the private sector and fourteen of those in the community sector. In the meantime, the participants in focus group discussions included seven persons working in the government sector, nine of those in the private sector and fourteen of those in the community sector. The collected qualitative data were analyzed with content analysis so as to yield the accurate results and data according to the research objectives.
\end{abstract}

Keywords:

Gastronomy, Tourism Development, Cultural Heritage Values

Article Received: 18 October 2020, Revised: 3 November 2020, Accepted: 24 December 2020

\section{Introduction}

The tourism industry in Thailand has expanded continuously, and this has helped to secure the country's sovereignty on the economy and society. The tourism industry is a magnet that fetches international currency for the country, while encouraging domestic employment and regional development (Ministry of Tourism and Sports, 20018 ). At present, the Thai tourism industry is introducing a new tourism measure, Creative Tourism. Their goal is to foster new experiences for the guests by exposing them to intact aspects of Thai culture and the Thai ways of life (CMU Data Compilation and Analysis, 2016). In order for this type of tourism to be successful, it is important to integrate technology into the management of Cultural Tourism. This attempt was prompted by the 12 th National Economic and Society Development Plan (2017-2021), which encourages economic development on the basis of knowledge and creativity. The national development plan encourages a"creative economy"by way ofestablishing"food city tourism" and by building the creative economy at the local and regional levels. The creative economy should also create added value to the services, which are related to local cultures via the integration of tourism knowledge and innovation and the diversity of cultural and environmental resources (Ministry of Tourism and Sports, 2016). 
Food is a Cultural Heritage of a community that generates creativity and mobilizeslife in big cities. Food is exploited for economic gain via a "creative economy", which a policy iscreated to boost the national economy. It has been co-articulated by Thailand's major schemes, including the 12 th National Economic and Society Development Plan (2017-2021), The Twenty-year National Strategy, and Thailand 4.0. Local Thai communitiesare encouraged to conduct their own creative economy, which should create added value for the local goods. When local products are being marketed, knowledge and innovation should be used. Because of its richness in cultural and environmental resources, Mahasarakham is one of fifteen Thai provinces and the only province in Northeastern Thailandthat has been given the title of "Creative Economic City" (Ministry of Tourism and Sports, 2016).

Therefore, the main objective of this research is to study and formulate a conceptual research framework for the development of Gastronomy Tourism in Mahasarakham. Therefore, a conceptual framework was developed to demonstrate these relationships between the factors ofCultural Heritage Values, Tourists'Motivations and Tourists' Experiences. The framework was proved by collecting the empirical data for quantitative analysis. The outcome revealed policies and strategies to develop local rice products to become the Tourism products by focusing on Cultural Heritage Values in MahasarakhamProvince.

\section{Literature Review}

\section{Cultural Heritage Values}

Cultural Heritage is a long and unique social artifact, which has been accumulated as a social construction. Culture is a reflection of the past successes and the wisdom that have been passed down from previous generations. (Aunkrisa Sangchumnong and Metin Kozak, 2016). Culture also refers to the root and origin of a nation that is worth preserving and maintaining for the next generation as a National Heritage
(Laaksonen, Annamari, 2014). There are two types of cultural heritage:Tangible Cultural Heritage and Intangible Cultural Heritage.Intangible Cultural Heritage is defined by UNESCO (2003) as those practices that represent theknowledge and skills that have been well-accepted by a community as a part of its own Cultural Heritage. Intangible Cultural Heritage is created and passed down through generations via word-of-mouth. Over time, this culture may undergo changes (UNESCO, 2007).The meaningof Intangible Cultural Heritage isCultural Heritage, which is intangible. It isunable to be touched and physically expressed (i.e.,the knowledge, meanings, beliefs, skills, norms, and traditions)that people or communities have created as a part of their lives and that has been transferred from one generation to the next up until the present. Cultural Heritage sites are, therefore, tangible heritage, which Aunkrisa Sangchumnong and Metin Kozakcomprise immovable cultural properties, which are inseparable from intangible Cultural Heritage (ICOMOS, 2003).Intangible Cultural Heritage is a gift from previous generations, which can be newly developed to serve the current needs of the community. It also makes one culture stand out fromanother (UNESCO, 2003).

Cultural Heritage not only holds physical value as an invention of the past civilization,but it also imposes a spiritual and mental hold on the people within a community. The followingisa list of qualities that make an artifact become eligible to be considered as Cultural Heritage:1) Holding historical, academic, and artistic values;2) Reflecting the evolution of lives and an ethical development from the past to the present;3) providingan historical footprint, which can be traced to its historical origins; 4) Being unique to one particular community and without being conserved could disappear easily; 5) Reflecting human creativity; 6) Showing the cultural roots of a community; 7) Representing individual or community values; and 8) Being at risk of becoming damaged or disappearing when left without conservation. 
Cultural Heritage is important because it holds the following values: 1) Historical and Anthropological ValueCultural Heritage portrays community and cultural evolution from the past to the present. It also narrates events relatedto the people and times in history. Beliefs and ideas, which are related to an invention, are embedded ineverysingle piece of cultural artifacts. 2) Social and Political Relation ValueCultural Heritage shows a unique connection between a community's past and its forms of politics and governance. It also narrates the past stories of ancient politics and past policies of governance. 3) Educational Valuethe remaining cultures of the past are a big reliable book that people in the presentcan study to see what was held in the past. Cultural Heritage is an important, rare, and enduring resource for present-day research, which helps the present-day learners to trace development back to the past,in which there are still a lot of hidden facts to be explored. 4) Aesthetic and Beauty ValueMost of the time,Cultural Heritage involves the great invention of a community, whichhas been beautifully crafted andcan make astrong impressionon

visit

5) ARepresentativeness ofRarity andIdentity ValueIn the present, those rare cultural artifacts that remain remind people of the beauty of the past cultures.

It can be concluded that the Cultural Heritage holds 19 types of values as follows: 1) Historical Value, 2) Social Value, 3) Living Value, 4) Traditional Value, 5) AuthenticValue 6) Beauty Value, 7)Rarity Value 8) Educational Value, 9) Narration Value, 10) Artistic Value, 11) Creativity Value, 12) Conservational Value, 13) Economic Value, 14) Social Image Value, 15) Identity Value,16) Aesthetic Value, 17) Anthropological Values, 18) Community Value,and 19)Archaeological Value.

\section{Tourism Motivations}

Abraham H.Maslow (1954) explained the following: 1) A man is born with needs which are endlessinnature. The needs that have been fulfilled can easily be replaced with other new needs, which means that needs for humans are a neverending process. Starting from the time when people are born until the time when they die, their needs continue. 2) The needs that have been fulfilled are no longer considered as needs; only the ones that are left without fulfillment are effective for behavioral causation. 3) There are hierarchies of needs starting from low-level needs to higher-level ones, andthe latter requirean immediate response. The five aspects of Maslow's Hierarchy of Needs, ranked from the lowest to the highest are presented below:

1. Physiological Needs are the basic needs for survival,including the need for the four requisites (food, water, air, and accommodation), compliments, and gender-related needs, among others.

2. Safety Needs are another form of survival needs, such as the need for career securityand the need for protection and safety.

3. Social Needs are the needs to be loved, to feel belongingness, and to be accepted as an existing member of a group in a social unit.

4. Esteem Needs are an individual's needs to:be outstanding, be recognized and to obtain social status and a higher level of relationship with other people, as well as to be respected socially.

5. Self-actualization Needsare at the top of the Hierarchy of Needs and are involved with being successful at a high level, which is reckoned by the public as special. This can be exemplified by a famous singer, who can master almost everything in his or her life.

In accordance with Maslow's Law of Inspiration, tourism inspiration is most of all triggered by the need to fulfill biological needs, followed by safety and security needs, relationship needs, self-esteem and development needs, and finally, the needs for happiness and fulfillment. The arrangement of individual needs, which are based on Maslow's Law,can help tourism operators to better cater to the tourists' requirements.

Actually, there are wide varieties of motivations that cause people to make tourism 
decisions. These can be categorized into two groups in tourism: Push Factors and Pull Factors. Push Factors are the motivators that make people have the desire to travel, while the pull factors are the elements that really cause them take a trip. Kirdsiri Jaleonwisan and Jutamat Jantarat (2000) proposed the following components of the Push Factors and the Pull Factors when deciding to take an overseas trip. The Push Factors for taking an overseas trip are: 1) the need for novelty, 2) the need for Knowledge, 3)the need for Prestige, 4)the need for relaxation,5) the need to Escape, 6) the need to visit relatives and friends,7) the need to goShopping, and 8) the need to continue one's education.

Based on their instincts, people desire to take a trip. However, tourism motivation is diversified in accordance with the individual's economic and social differences. Below is a list of reasons why people take tours: 1)the need to not be entwined with daily routines, 2)the need for excitement,3) the desire to learn something new and novel, 4)the wish to see different social values, 5) the need to explore different cultures, 6) the need to visit friends and relatives, 7) the desire to learn about different ways of life, 8) the need for social recognition, 9) the need for prestige,10) the need for social status, 11)the need to recall the past,12) the need for pleasure, and 13) the need for physical and mental resilience.

\section{Tourists' Experiences}

Laing, Wheeler, Reeves \& Frost (2014) stated that an individual's experience can affect his or her trip, and it is important to foster a positive experience for the tourists. Foster (2014) says holidays are established to allow for excitement and fun experiences. Pine \& Gilmore (1999) noted that tourists want to experience excitement and have good memoriesof their trip. Mei (2014) stated thatmaking travel decisionsis a complex process, which is related to psychological reasons that are diversified from person to person. Neuhofer \& Buhallis (2014) indicatedthat the operators, who can create an impressive experience for tourists, usually gain higher competitive power than other firms, which don't have the same ability. Stamboulis \& Skayannis (2003) suggested that a "tourism experience" is a connection between the tourists and the places that they visit. Richards (2001)notedthat tourism firms can attract tourists via broadcasting the past experiences of the former tourists in order to attract new groups of tourists. Wang, Xiang, \& Fesenmaier(2014)stated that the tourism experience can be included in the tourism package. Kim, Hallab \& Kim (2012) found that the past tourism experiencesare simulatorsfor the next tourism decision. Impressions related to services, cultural values, and the imagination of the place they are visiting, are the motives for tourism decisions.Tan (2016) stated that tourism scenes are the magnets that prompt former tourists to revisit the locales. It was observed from interviewing the samples for this study that familiarity and having an impressive experience had affected the tourists' decisions to revisit. However, for those revisiting tourists, whose purpose for tourism was to obtain relaxation, it was found their experience and the image of the tourism destination had nothad any impact on their decision to revisit a destination.Poulsson \& Kale (2004) statedthat true tourism experiences can only be generated when tourists take part in tour activities, which have been designed to expose the tourists to learning and to assist them in coming intocontact with other tourists. Meanwhile, it is equally important for the activities to be fun and novel for the tourists. Sonmez \& Graefe (1998) explained that whether or not tourists would choose to return to the same tourism sites depended upon their past experienceson their previous visits. The level of risk at a site and the security systems, which have been put in place there, are the two reasons that have the power to make one tourism attraction become more or less popular among the tourists. These are, of course, factorsthat affect the tourists' decisions torevisit a place. A country with lower levels of risk and higher levels of security can become a favorite overseasdestination for foreign tourists. Having had an impressive past 
experience is a key factor thatcan make tourists want to return, while risk and security factors can also contribute to the creation of loyaltyfrom the tourists.
Relevant Variables and Factors, which werefound inthe review of the literature on Gastronomy Tourism and which focus on the values of Cultural Heritage,are summarized in Table 1.

Table 1. Key Factors in the Supporting Literature

\begin{tabular}{|c|c|}
\hline Factor Identification & Supporting Literature \\
\hline \multicolumn{2}{|r|}{ Cultural Heritage Values } \\
\hline - Historical Value & $\begin{array}{l}\text { UNESCO (2003), UNESCO (2007), } \\
\text { Thailand Charter for Cultural Heritage Management (2011), Department of } \\
\text { Cultural Promotion (2013), } \\
\text { Kanjana Sanglimsuwan \& Saranya Sanglimsuwan (2014), Keitumetse S. } \\
\text { O.(2014), Li Chuo (2015) }\end{array}$ \\
\hline - Living Value & $\begin{array}{c}\text { UNESCO (2003), UNESCO (2007), } \\
\text { Thailand Charter for Cultural Heritage Management (2011), } \\
\text { Department of Cultural Promotion (2013) }\end{array}$ \\
\hline - Authenticity Value & $\begin{array}{c}\text { UNESCO (2003), UNESCO (2007), } \\
\text { Thailand Charter for Cultural Heritage Management (2011), Department of } \\
\text { Cultural Promotion (2013) }\end{array}$ \\
\hline - Story Value & $\begin{array}{c}\text { UNESCO (2003), UNESCO (2007), } \\
\text { Thailand Charter for Cultural Heritage Management (2011), Department of } \\
\text { Cultural Promotion (2013) }\end{array}$ \\
\hline - Creative Value & $\begin{array}{c}\text { UNESCO (2003), UNESCO (2007), } \\
\text { Thailand Charter for Cultural Heritage Management (2011), } \\
\text { Department of Cultural Promotion (2013) }\end{array}$ \\
\hline - Economic Value & $\begin{array}{l}\text { UNESCO (2003), UNESCO (2007), } \\
\text { Thailand Charter for Cultural Heritage Management (2011), Department of } \\
\text { Cultural Promotion (2013) }\end{array}$ \\
\hline - Aesthetic value & $\begin{array}{c}\text { UNESCO (2003), UNESCO (2007), } \\
\text { Thailand Charter for Cultural Heritage Management (2011), Department of } \\
\text { Cultural Promotion (2013) }\end{array}$ \\
\hline - Social Value & $\begin{array}{c}\text { UNESCO (2003), UNESCO (2007), } \\
\text { Thailand Charter for Cultural Heritage Management (2011), Department of } \\
\text { Cultural Promotion (2013) }\end{array}$ \\
\hline - Traditional Value & $\begin{array}{c}\text { UNESCO (2003), UNESCO (2007), } \\
\text { Thailand Charter for Cultural Heritage Management (2011), Department of } \\
\text { Cultural Promotion (2013) }\end{array}$ \\
\hline - Educational Value & $\begin{array}{c}\text { UNESCO (2003), UNESCO (2007), } \\
\text { Thailand Charter for Cultural Heritage Management (2011), Department of } \\
\text { Cultural Promotion (2013) }\end{array}$ \\
\hline - Artistic Value & $\begin{array}{c}\text { UNESCO (2003), UNESCO (2007), } \\
\text { Thailand Charter for Cultural Heritage Management (2011), Department of } \\
\text { Cultural Promotion (2013) }\end{array}$ \\
\hline - Conservation Value & $\begin{array}{l}\text { UNESCO (2003), UNESCO (2007), } \\
\text { Thailand Charter for Cultural Heritage Management (2011), Department of } \\
\text { Cultural Promotion (2013), } \\
\text { Kanjana Sanglimsuwan \& Saranya Sanglimsuwan (2014), Keitumetse } \\
\text { S.O.(2014), Li Chuo (2015) }\end{array}$ \\
\hline - Identity Value & $\begin{array}{c}\text { UNESCO (2003), UNESCO (2007), } \\
\text { Thailand Charter for Cultural Heritage Management (2011), Department of } \\
\text { Cultural Promotion (2013) }\end{array}$ \\
\hline
\end{tabular}




\begin{tabular}{|c|c|}
\hline Factor Identification & Supporting Literature \\
\hline - Community Value & $\begin{array}{c}\text { UNESCO (2003), UNESCO (2007), } \\
\text { Thailand Charter for Cultural Heritage Management (2011), Department of } \\
\text { Cultural Promotion (2013) }\end{array}$ \\
\hline - Anthropological Value & $\begin{array}{l}\text { UNESCO (2003), UNESCO (2007), } \\
\text { Thailand Charter for Cultural Heritage Management (2011), Department of } \\
\text { Cultural Promotion (2013) }\end{array}$ \\
\hline - Political Relation Value & $\begin{array}{c}\text { UNESCO (2003), UNESCO (2007), } \\
\text { Thailand Charter for Cultural Heritage Management (2011), Department of } \\
\text { Cultural Promotion (2013) }\end{array}$ \\
\hline - Beauty Value & $\begin{array}{c}\text { UNESCO (2003), UNESCO (2007), } \\
\text { Thailand Charter for Cultural Heritage Management (2011), Department of } \\
\text { Cultural Promotion (2013) }\end{array}$ \\
\hline - Rarity Value & $\begin{array}{c}\text { UNESCO (2003), UNESCO (2007), } \\
\text { Thailand Charter for Cultural Heritage Management (2011), Department of } \\
\text { Cultural Promotion (2013) }\end{array}$ \\
\hline \multicolumn{2}{|r|}{ Tourists' Motivations } \\
\hline - Prestige & $\begin{array}{l}\text { Kirdsiri Jaleonwisan and Jutamat Jantarat (2000), } \\
\text { Nagin, Daniel, S., James B. Rebitzer, Seth Sanders, and Lowell J. Taylor } \\
\qquad(2002), \\
\text { Kim, H., Woo, H., \& Uysal, M. (2015), } \\
\text { Stephen Chaney \&Chris Pyan (2012), } \\
\text { Athena. Mak, Margaret Lumbers, Anita Eves \& Richard C. Y. Chang. (2012). } \\
\text { Athena. Mak, Margaret Lumbers, Anita Eves\& Richard C. Y. Chang. (2017), } \\
\text { Ja Young (Jacey) Choe, Seongseop (Sam) Kim (2019), }\end{array}$ \\
\hline - Status & $\begin{array}{l}\text { Otto and Pitchie (1996), Nagin, Daniel, S., James B. Rebitzer, Seth Sanders, } \\
\text { and Lowell J. Taylor. (2002). Kim, H., Woo, H., \& Uysal, M. (2015), Le Bel, } \\
\text { Sears and Dube (2004), } \\
\text { Chang and Yuan (2011), } \\
\text { Stephen Chaney \& Chris Pyan (2012), } \\
\text { Peter Bjork, Hannele Kauppinen - Raisanen (2019), } \\
\text { Ja Young (Jacey) Choe, Seongseop (Sam) Kim (2019), }\end{array}$ \\
\hline - Health Concerns & $\begin{array}{l}\text { Otto and Pitchie (1996), Kim, H., Woo, H., \& Uysal, M. (2015), } \\
\text { Kim and Eves (2012), Stephen Chaney \&Chris Pyan (2012), } \\
\text { Athena. Mak, Margaret Lumbers, Anita Eves \& Richard C. Y. Chang. (2012). } \\
\text { Athena. Mak, Margaret Lumbers, Anita Eves \& Richard C. Y. Chang. (2017). } \\
\text { Ja Young (Jacey) Choe, Seongseop (Sam) Kim (2019) }\end{array}$ \\
\hline - Culture & $\begin{array}{l}\text { Kirdsiri Jaleonwisan and Jutamat Jantarat (2000), } \\
\text { Nagin, Daniel, S., James B. Rebitzer, Seth Sanders, and Lowell J. Taylor } \\
\qquad(2002), \\
\text { Kivlta and Crotts (2009), } \\
\text { Kim, H., Woo, H., \& Uysal, M. (2015), Kim and Eves (2012), } \\
\text { Athena. Mak, Margaret Lumbers, Anita Eves\& Richard C. Y. Chang (2012), } \\
\text { Athena. Mak, Margaret Lumbers, Anita Eves\& Richard C. Y. Chang (2017) }\end{array}$ \\
\hline - Escape from routines & $\begin{array}{c}\text { Otto and Pitchie (1996), Pine and Gilmore (1999), } \\
\text { Kirdsiri Jaleonwisan and Jutamat Jantarat (2000), } \\
\text { Kim\&Searles (2009) }\end{array}$ \\
\hline - Pleasures & $\begin{array}{c}\text { Kirdsiri Jaleonwisan and Jutamat Jantarat (2000), } \\
\text { Le Bel, Sears and Dube (2004), } \\
\text { Stephen Chaney \& Chris Pyan (2012), } \\
\text { Athena. Mak, Margaret Lumbers, Anita Eves\& Richard C. Y. Chang (2012), }\end{array}$ \\
\hline - Sensory appeal & $\begin{array}{c}\text { Le Bel, Sears and Dube (2004), } \\
\text { Stephen Chaney \& Chris Pyan (2012), Kim and Eves (2012), }\end{array}$ \\
\hline
\end{tabular}




\begin{tabular}{|c|c|}
\hline Factor Identification & Supporting Literature \\
\hline & $\begin{array}{l}\text { Athena. Mak, Margaret Lumbers, Anita Eves \& Richard C. Y. Chang (2012), } \\
\text { Athena. Mak, Margaret Lumbers, Anita Eves \& Richard C. Y. Chang (2017), }\end{array}$ \\
\hline - Excitement & $\begin{array}{l}\text { Kim, H., Woo, H., \& Uysal, M. (2015), } \\
\text { Stephen Chaney \& Chris Pyan (2012), Kim and Eves (2012), } \\
\text { Athena. Mak, Margaret Lumbers, Anita Eves \& Richard C. Y. Chang (2012), }\end{array}$ \\
\hline - Togetherness & $\begin{array}{c}\text { Kim, H., Woo, H., \& Uysal, M. (2015), } \\
\text { Stephen Chaney\& Chris Ryen (2011), } \\
\text { Chang and Yuan (2011), Athena. Mak, Margaret Lumbers, Anita Eves \& } \\
\text { Richard C. Y. Chang (2012) }\end{array}$ \\
\hline - Interpersonal & $\begin{array}{l}\text { Otto and Pitchie (1996), } \\
\text { Nagin, Daniel, S., James B. Rebitzer, Seth Sanders, and Lowell J. Taylor } \\
\text { (2002), } \\
\text { Kim, H., Woo, H., \& Uysal, M. (2015), } \\
\text { Kim and Eves (2012), Athena. Mak, Margaret Lumbers, Anita Eves \& } \\
\text { Richard C. Y. Chang (2017) }\end{array}$ \\
\hline - Physical and Mental Resilience & Kirdsiri Jaleonwisan and Jutamat Jantarat (2000) \\
\hline - A Recollection of the Past & Kirdsiri Jaleonwisan and Jutamat Jantarat (2000) \\
\hline - Social Recognition & Kirdsiri Jaleonwisan and Jutamat Jantarat (2000) \\
\hline - Different ways of Living & Kirdsiri Jaleonwisan and Jutamat Jantarat (2000) \\
\hline - Relaxation & Kirdsiri Jaleonwisan and Jutamat Jantarat (2000) \\
\hline \multicolumn{2}{|r|}{ Tourists' Experiences } \\
\hline - Hedonism & $\begin{array}{l}\text { Otto and Richie (1996), Charles A Adongo et al. (2015), } \\
\text { Mei-Jung Wang, Li-Hin Chen, Po-an Su, Alastair M. Morrison (2019), }\end{array}$ \\
\hline - Novelty & $\begin{array}{c}\text { Kirdsiri Jaleonwisan and Jutamat Jantarat (2000), } \\
\text { Otto and Richie (1996), } \\
\text { Nagin, Daniel, S., James B. Rebitzer, Seth Sanders, and Lowell J. Taylor } \\
\text { (2002), Chang and Yuan (2011), } \\
\text { Stephen Chaney\& Chris Pyan (2012), } \\
\text { Charles A. Adongo et al. (2015), } \\
\text { Athena. Mak, Margaret Lumbers, Anita Eves \& Richard C. Y. Chang(2017), } \\
\text { Mei-Jung Wang, Li-Hin Chen, Po-an Su, Alastair M. Morrison (2019) }\end{array}$ \\
\hline - Local Culture & $\begin{array}{l}\text { Charles A. Adongo et al (2015), } \\
\text { Nagin, Daniel, S., James B. Rebitzer, Seth Sanders, and Lowell J. Taylor } \\
\text { (2002), } \\
\text { Kivlta and Crotts (2009), Kim and Eves (2012), } \\
\text { Athena. Mak, Margaret Lumbers, Anita Eves \& Richard C. Y. Chang (2012), } \\
\text { Mei-Jung Wang, Li-Hin Chen, Po-an Su, Alastair M. Morrison (2019), }\end{array}$ \\
\hline - Refreshment & $\begin{array}{c}\text { Cohen (1979), Otto and Richie (1996), } \\
\text { Kim, H., Woo, H., \& Uysal, M. (2015), } \\
\text { Le Bel, Sears and Dube (2004), } \\
\text { Mei-Jung Wang, Li-Hin Chen, Po-an Su, Alastair M. Morrison (2019), }\end{array}$ \\
\hline - Meaningfulness & $\begin{array}{l}\text { Pine and Gilmor (1999), Charles A Adongo et al. (2015), } \\
\text { Mei-Jung Wang, Li-Hin Chen, Po-an Su, Alastair M. Morrison (2019) }\end{array}$ \\
\hline - Involvement & $\begin{array}{c}\text { Otto and Richie (1996), } \\
\text { Kim and Eves (2012), Stephen Chaney\& Chris Pyan (2012) } \\
\text { Athena. Mak, Margaret Lumbers, Anita Eves \& Richard C. Y. Chang (2017), } \\
\text { Mei-Jung Wang, Li-Hin Chen, Po-an Su, Alastair M. Morrison (2019), }\end{array}$ \\
\hline - Knowledge & $\begin{array}{c}\text { Pine and Gilmor (1999), } \\
\text { Kirdsiri Jaleonwisan and Jutamat Jantarat (2000), } \\
\text { Kim and Eves (2012), } \\
\text { Stephen Chaney \& Chris Pyan (2012), } \\
\text { Charles A. Adongo et al. (2015), } \\
\text { Mei-Jung Wang, Li-Hin Chen, Po-an Su, Alastair M. Morrison (2019), }\end{array}$ \\
\hline
\end{tabular}




\begin{tabular}{|c|c|}
\hline Factor Identification & Supporting Literature \\
\hline - Adverse Experiences & Cohen (1979),Stephen Chaney \&Chris Pyan (2012), \\
& Charles A. Adongo et al. (2015), \\
& Mei-Jung Wang, Li-Hin Chen, Po-an Su, Alastair M. Morrison (2019), \\
\hline - Good Memories & Richards (2001), Stamboulis \& Skayannis (2003), \\
& Tan (2016), \\
\hline - Service & Richards (2001), Stamboulis \& Skayannis (2003), \\
& Tan (2016), Peter Bjork, Hannele Kauppinen - Raisanen (2019) \\
\hline - Value & Richards (2001), Stamboulis \& Skayannis (2003), \\
& Tan (2016), Peter Bjork, Hannele Kauppinen - Raisanen (2019) \\
\hline - Security System & Kirdsiri Jaleonwisan and Jutamat Jantarat (2000), \\
& Richards (2001), Stamboulis \& Skayannis (2003), \\
Tan (2016) \\
\hline - Imagination & Richards (2001), Stamboulis \& Skayannis (2003), \\
& Tan (2016) \\
\hline - Past Experiences & Tichards (2001), Stamboulis \& Skayannis (2003), \\
& Tan (2016) \\
\hline - Connection & Kirdsiri Jaleonwisan and Jutamat Jantarat (2000), \\
& Richards (2001), Stamboulis \& Skayannis (2003), \\
& Tan (2016), \\
\hline - Education & Kirdsiri Jaleonwisan and Jutamat Jantarat (2000), \\
& Pine and Gilmor (1999), Charles A Adongo et al. (2015) \\
\hline
\end{tabular}

\section{Research Method}

Conducting in-depth interviews is a qualitative research technique that involves conducting intensive individual interviews with a small number of respondentsin order to explore their perspectives on particular ideas, programs, or situations. The process for conducting in-depth interviews follows the same general process, which is followed in other research studies: planning, developing instruments, collecting data, analyzing data, and disseminating findings (Carolyn Boyce, 2006). The research started with identifying the factors, which were related to the theories and the literature, such as research articles and text books. The in-depth interviews wereused as the tool to confirm the factors, to deeply explore new issues,and to formulate the conceptual research model in accordance withthe following steps:

Step 1. Identifyingthe stakeholders, who will be involved. There were 3 different sample groups, who were involved in Gastronomy Tourism Development Focusing on Cultural Heritage Values in Mahasarakham Province.

Step 2. Identifyingthe information that would be needed and from whom it would be gathered. The respondents consisted of 9 representatives from government agencies and the private sector, 3 entrepreneurs, and 3 community members. In order to cover the research issues and to collect comments from each group of experts, the questions were broad and open-ended. Moreover, the questions were divided in to 6 parts:

1. Personal Information

2. The Cultural Heritage Value of Local Food in Mahasarakham Province.

3. The Motivation of Tourists engaged in Gastronomy Tourism in Mahasarakham Province

4. The Tourists' Experiencesfrom thoseengaged in Gastronomy Tourism in Mahasarakham Province.

5. The Strategies for the Development of Gastronomy Tourism focusing on the Cultural Heritage Values in Mahasarakham Province.

6. Opinion and Suggestions.

Step 3. Analyzing all of the interview data. Reading through the interview responses and looking for patterns or themes among the participants. 


\section{Results}

According to the literature review and the opinions of the 15 interviewees, the indicators for the Development of Gastronomy Tourism, focusing on the confirmed factors and items of Cultural Heritage Values in Mahasarakham Province, are listed in Table 2.

Table 2.Factors and Items

\begin{tabular}{|c|c|c|}
\hline Factors & Intermediate Factors & Items \\
\hline \multirow[t]{9}{*}{$\begin{array}{l}\text { Cultural } \\
\text { Heritage Values }\end{array}$} & Historical Value & $\begin{array}{l}\text { HV1 Story Telling } \\
\text { HV2 Life Style } \\
\text { HV3 Local Legend }\end{array}$ \\
\hline & Living Value & $\begin{array}{l}\text { LV1 Wisdom } \\
\text { LV2 Skill } \\
\text { LV3 Folk }\end{array}$ \\
\hline & Authenticity Value & $\begin{array}{l}\text { AUV1 Process } \\
\text { AUV2 Taste } \\
\text { AUV3 Atmosphere }\end{array}$ \\
\hline & Aesthetic value & $\begin{array}{l}\text { ASV1 Artistry } \\
\text { ASV2 Creative } \\
\text { ASV3 Decoration }\end{array}$ \\
\hline & Economic Value & $\begin{array}{l}\text { EV1 CommunityEnterprise } \\
\text { EV2 Value Added } \\
\text { EV3 Tourism Product }\end{array}$ \\
\hline & Social Value & $\begin{array}{l}\text { SV1 Belief } \\
\text { SV2 Norm } \\
\text { SV3 Tradition }\end{array}$ \\
\hline & Educational Value & $\begin{array}{l}\text { ED1 Importance } \\
\text { ED2 Training } \\
\text { ED3 Knowledge }\end{array}$ \\
\hline & Conservation Value & $\begin{array}{l}\text { CS1 Inheritance } \\
\text { CS2 Being Lost } \\
\text { CS3 Significance }\end{array}$ \\
\hline & Identity Value & $\begin{array}{l}\text { IV1 Rarity } \\
\text { IV2 Unique } \\
\text { IV3 Characteristic }\end{array}$ \\
\hline \multicolumn{2}{|l|}{ Tourists' Motivations } & $\begin{array}{l}\text { TM1: Prestige } \\
\text { TM2: Status } \\
\text { TM3: Health Concern } \\
\text { TM4: Culture } \\
\text { TM5: Escape form Routine } \\
\text { TM6: Pleasure } \\
\text { TM7: Sensory Appeal } \\
\text { TM8: Excitement } \\
\text { TM9: Togetherness } \\
\text { TM10: Interpersonal }\end{array}$ \\
\hline \multicolumn{2}{|l|}{ Tourists' Experiences } & $\begin{array}{l}\text { TE1: Hedonism } \\
\text { TE2: Novelty } \\
\text { TE3: Local Culture } \\
\text { TE4: Refreshment } \\
\text { TE5: Meaningfulness } \\
\text { TE6: Involvement } \\
\text { TE7: Knowledge } \\
\text { TE8: Adverse Experience }\end{array}$ \\
\hline
\end{tabular}


The characteristics of the Cultural Heritage Values were comprised of nine factors and each factor was further comprised of three items. The characteristics of the Tourists' Motivations was comprised of ten items, while thecharacteristics of the Tourists' Experienceswere comprised of eight items. The conceptual research model, as shown in Figure 1, wasthen constructed. Moreover, in order to show these items and their indicators in greater detail, the framework was further extended as shown in Figure 2.

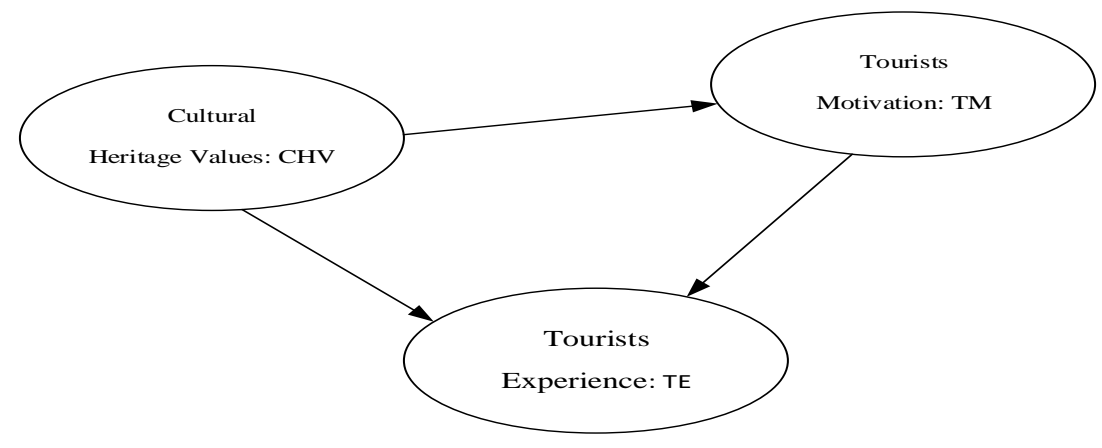

Figure 1. The Conceptual Framework

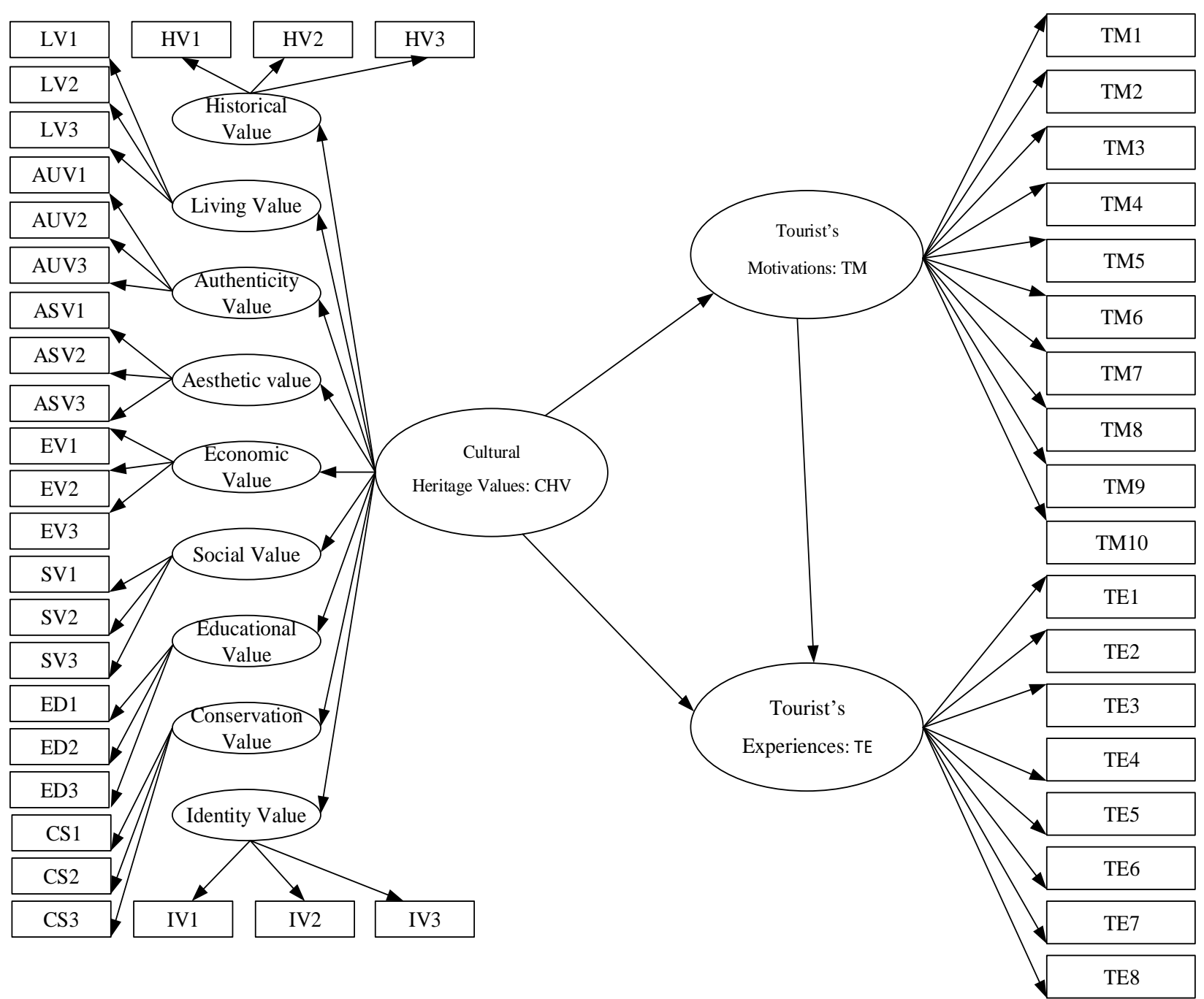

Figure 2. The Details of the Conceptual Framework 


\section{Conclusions}

This research studied the factors, which were related to the development of Gastronomy Tourism, focusing on Cultural Heritage Value. A conceptual framework was modelled to study the factors and items related to the development of Gastronomy Tourismin Mahasarakham Province. Relevant literature and theories, associated withthe values of Cultural Heritage, Tourists' Motivations, and Tourists' Experiences, were identified. From reviewing the literature, groups of factors were compiled. Afterwards, these factors were confirmed by using in-depth interviews to surveythe 3 groups, who were involved in theDevelopment of Gastronomy Tourism focusing on Cultural Heritage Values in Mahasarakham Province. For example, based on the recommendations from the experts, some of the factors acquired more item due to the fact that the factors should be more descriptive andgive further details about the local culture in Mahasarakham Province. The process of developing the framework can be used as a guideline for the future development of other types of tourism and can be applied to other regionshaving similar types of culture.

\section{Acknowledgements}

This research study was supported by the National Research Council of Thailand (NRCT) : Research Scholarship for Graduate Students in 2018.

This article is part of a thesis entitled, "Innovation for Gastronomy Tourism Development Focusing on Local Rice Products and the Cultural Heritage Values of Mahasarakham Province" for the Doctor of Philosophy Program in Tourism and Hospitality Innovation Management at the Faculty of Business Administration and Accountancy(KKBS) at Khon Kaen University in Thailand.

\section{References}

[1] Abraham H. Maslow (1954). Motivation and personality. New York : Harper and Row.

[2] Aunkrisa Sangchumnong and Metin Kozak. (2016). Sustainable Cultural Heritage Tourism Development Model at Ban Wangka Mon Village, Kanchanaburi Province, Thailand. 8th World Conference for Graduate Research in Tourism, Hospitality and Leisure: 173-178.

[3] Athena. Mak, Margaret Lumbers, Anita Eves \& Richard C. Y. Chang. (2017). The effects of food-related personality traits on tourist food consumption motivations, Asia Pacific Journal of Tourism Research, 22:1, 1-20.

[4] Athena. Mak, Margaret Lumbers, Anita Eves \& Richard C. Y. Chang. (2012). Factors Influencing Tourist Food Consumption. International Journal of Hospitality Management, 31(3), September 2012, 928-936.

[5] Babu, R. Hemanth, T. Raja Reddy, and N. Giri Babu. "Role of Information Technology and Analysis of Various Frameworks in Customer Relationship Management." International Journal of Sales \& Marketing Management (IJSMM) 5.3 (2016): 1-6.

[6] Beg, Sana. (2017). STRATEGIC FRAMEWORK FOR INTRODUCTION OF ISLAMIC BANKING IN INDIA. International Journal of Economics, Commerce and Research (IJECR), 7.4(2017), 75-84.

[7] Carolyn Boyce. (2006). CONDUCTING IN-DEPTH INTERVIEWS: A Guide for Designing and Conducting In-Depth Interviews for Evaluation Input. PATHFINDER INTERNATIONAL TOOL SERIES. Monitoring and Evaluation -2 .

[8] Chang and Yuan (2011). Creativity and Taoism: A Study of Chinese Philosophy, Art and Poetry.London and Philadelphia: 
Singing Dragon an imprint of Jessica Kingsley Publishers.

[9] Charles A. Adongo et al. (2015). Will they tell others to taste? International tourists' experience of Ghanaian cuisines. Tourism Management Perspectives, 15(2015), 57-64.

[10] Cohen and Avieli (2004). Food in tourism: Attraction and Impediment. Annals of Tourism Research 31(4), October 2004, 755-778.

[11] CMU Data Compilation and Analysis.(2 $\begin{array}{lllllll} & 0 & 1 & 6 & \text { ) } & \text {. Tourism }\end{array}$ Principle.Retrieved June 5, 2017, from file://C:/Users/Administrator/Downloads/ 363-1090-1-PB.pdf.

[12] Department of Cultural Promotion. (2013). UNESCO assembles peoples around transnational traditions like couscous, one of 32 new inscriptions on its Intangible Heritage Lists. Retrieved June 5, 2017, from https://ich.unesco.org/?heavy_load

[13] Elwakeel, Mohamed Ahmed Said, and Ahmed Mohamed Elnoury. (2018). EFFECTIVENESS OF PORT STATE CONTROL INSPECTIONS WITHIN THE FRAMEWORK OF THE MEDITERRANEAN MEMORANDUM OF UNDERSTANDING. IMPACT: International Journal of Research in Engineering \& Technology, 6.6(2018), 2130.

[14] Foster, G.D. (2014). Placement and promotion strategies to increase sales of healthier products in supermarkets in lowincome, ethnically diverse neighborhoods: a randomized controlled trial. The American Journal of Clinical Nutrition, 99(6), 13591368 .

[15] Frnacis, Leena, and C. Sengottuelu. (2017). DEVELOPMENT OF HRM FRAMEWORK FOR QUALITY MANAGEMENT: EMPIRICAL ANALYSIS OF HRM CHALLENGES. International Journal of Human Resource
Management

and

Research (IJHRMR), 7.5(2017), 23-30.

[16] Hao, Chen-Yu, et al. (2016). THE DESIGN AND IMPLEMENTATION OF INTEROPERABILITY FRAMEWORK FOR CROSS-NATIONS FLOOD DISASTER WARNING SYSTEM. International Journal of Computer Science and Engineering (IJCSE), 5.2(2016), 2332.

[17] ICOMOS. (2003). ICOMOS Principles for the Preservation and Conservation/Restoration of Wall Paintings. Retrieved June 5, 2017, from https://www.icomos.org/en/what-wedo/focus/179-articles-enfrancais/ressources/charters-andstandards/166-icomosprinciples-for-thepreservation-and-conservationrestorationof-wall-paintings

[18] Ja Young (Jacey) Choe (2019). Development and validation of a multidimensional tourist's local food consumption value (TLFCV) scale. International Journal of Hospitality Management, 77(2019), 245-259.

[19] Kanjana Sanglimsuwan \& Saranya Sanglimsuwan. (2014). Sustainable Cultural Heritage Tourism. Executive Journal, 12(October-December), 139-146.

[20] Keitumetse, S.O. (2014). Southern Africa: Cultural heritage tourism development and management. Retrieved June 5, 2017, from https://doi.org/10.1007/978-1-4419-04652_13.

[21] Kim \& Eves. (2012).Construction and validation of a scale to measure tourist motivation to consume local food. Tourism Management, 33(6),1458-1467.

[22] Kim, H., Woo, H., \& Uysal, M. (2015). Tourism experience and quality of life among elderly tourists. Tourism Management, 46, 465-476.

[23] Kim, K., Hallab, Z., \& Kim, J.N. (2012). The Moderating Effect of Travel Experience in a Destination on the 5839 
Relationship between the Destination Image and the Intention to revisit. Hospitality Marketing\& Management, 21(5), 486-505.

[24] Kirdsiri Jaleonwisan \& Jutamat Jantarat. (2000). The contentment and motivation for tourism: To promote Thailand to Thailand. TAT Review Magazine, 4(2000), October-December.

[25] Kivela, J., Crotts, J. (2005). Gastronomy and tourism: A meaningful travel market segment. Journal of Culinary Science \& Technology, 4(2/3), 39-55.

[26] Kivela, J., Crotts, J. (2009). Etymology and gastronomy: Gastronomy's influence on how tourists experience a destination. Journal of Hospitality \& Tourism Research, 30, 354-377.

[27] Kunkaew Khlaikaew. (2015). The Cultural Tourism Management under Context of World Heritage Sites: Stakeholders'Opinions between Luang Prabang Communities, Laos and Muangkao Communities, Sukhothai,Thailand. 2nd GLOBAL CONFERENCE on BUSINESS, ECONOMICS, MANAGEMENT and TOURISM, 30-31 October 014, Prague, Czech Republic. Procedia Economics and Finance, 23(2015), 1286 - 1295.

[28] Laaksonen, Annamari. (2014). Cultural policies and the 2005 UNESCO Convention in Asia. Research and report prepared by Annamari Laaksonen, Research Manager, IFACCA, with the support of UNESCO Bangkok Officewww.ifacca.org

[29] Le Bel, Sears and Dube. (2004).Experiential tourism: Preliminary scale development to assess pleasurable experiences. Paper Present at the Proceedings of the 35th annual conference of the Travel and Tourism Research Association, Montreal, Canada.
[30] Laing, J., Wheeler, F., Reeves, K., \& Frost, W. (2014). Sustainable Tourism and Indigenous Peoples. Retrieved June 5, 2017, from https://books.google. co.th/books?.

[31] Li, Chuo (2015). Commercialism and identity politics in New York's Chinatown Published. Retrieved January 30, 2015, from https://doi.org/10.1177/ 0096144214566956

[32] Mei, X.Y. (2014). Boring and expensive: The challenge of developing experiencebased Tourism intheInlandregion, Norway. Retrieved June 5, 2017, from https://doi.org/10.1016/j.tmp.2014.09.003.

[33] Ministry of Tourism and Sports, Thailand. (2016). Tourism is the main income of Thailand. Retrieved April 20, 2018, from http://www.tica.or.th/images/ plan_tourism2560-2564/2560-2564.pdf.

[34] Ministry of Tourism and Sports, Thailand. (2018). Tourism Statistics 2018. Retrieved April 20, 2018, from https://www.mots.go.th/more_news_new.p hp?cid=497.

[35] Mira Burri. (2018). Cultural Heritage and Intellectual Property. Forthcoming in The Oxford Handbook of International Cultural Heritage Law, edited by Francesco Francioni and Ana Vrdoljak (Oxford University Press, 2019).

[36] Mitra, Dipa. (2017). AN ANALYTICAL FRAMEWORK ON LEADERSHIP EFFECTIVENESS WITH SPECIAL REFERNCE TO INDIAN TELLECOMMUNICATION

INDUSTRY. IMPACT: International Journal of Research in Business Management (IMPACT: IJRBM), 5.10(2017), 1-16.

[37] Nagin, Daniel, S., James B. Rebitzer, Seth Sanders, and Lowell J. Taylor. (2002). "Monitoring, Motivation, and Management: The Determinants of Opportunistic Behavior in a Field 
Experiment ." American Economic Review, 92 (4): 850-873.

[38] Neuhofer, B. (2014). A typology of technology-enhanced tourism experiences. International Journal of Tourism Research, 16(4), 340-350.

[39] Office of the National Economic and Social Development Board Office of the Prime MinisterBangkok, Thailand. (2017). The 12th National Economic and Society Development Plan. (2017-2021). Retrieved June 5, 2017, from https://www.nesdc.go.th/ewt_dl_link.php? nid $=9640$

[40] Otto, J.E. \& Ritchie, J. (1996) The Service Experience in Tourism. Tourism Management, 17, 165-174.

[41] Peter Björk Hannele \& Kauppinen Räisänen. (2014),"Culinary-gastronomic tourism - a search for local food experiences". Nutrition \& Food Science, 44(4), $294-309$.

[42] Pine, G. (1999). Pine and Gilmore's concept of experience economy and its dimensions: An empirical examination in tourism. Journal of Quality Assurance in Hospitality \& Tourism, 12(4), 237-255.

[43] Poulsson, K. (2004). The experience economy and commercial experiences. TheMarketing Review, 4(3), 267-277.

[44] Richards, J.C. (2001). Curriculum Development in Language Teaching. Cambridge:Cambridge University Press.

[45] Sonmez, G. (1998). Determining future travel behavior from past travel experience and perceptions of risk and safety. Travel Research, 37(2), 171-177.

[46] Stamboulis \& Skayannis. (2003). Innovation strategies and technology for experience-based tourism. Tourism Management, 24(1), February 2003, 35-43.

[47] Stephen Chaney \& Chris Ryan. (2012). Analyzing the evolution of Singapore's World Gourmet Summit: An example of Gastronomic Tourism. International Journal of Hospitality Management, 31(2012), 309-318.
[48] Tan. (2016). Completing China's Interest Rate Liberalization. Retrieved June 5, 2017 , from https://doi.org/10.1111/cwe.12148.

[49] Thailand Charter for Cultural Heritage Management. (2011). Retrieved June 5, 2017, from http://www.icomosthai.org/THcharter/Thai land\%20Charter(1).pdf

[50] Tinikan Prakraiwan. (2016). Cultural Tourism Route of Thai Wayof Life along Bangkok Canal. Najua Special Issue, 31(4), 134-157.

[51] UNESCO. (2003). ICOMOS Principles for the Preservation and Conservation/Restoration of Wall Paintings. Retrieved June 5, 2017, from https://www.icomos.org/en/what-wedo/focus/179-articles-enfrancais/ressources/charters-andstandards/166-icomosprinciples-for-thepreservation-and-conservationrestorationof-wall-paintings

[52] UNESCO. (2007). GMS Training of Trainer workshop for cultural tourism management and guidingstandards. UNESCO.

[53] Wang, D., Park, S., \& Fesenmaier, D. R. (2014). The role of smartphones in mediating thetouristic experience. Journal of Travel Research, 51(4), 371-387. 